Vol. 18 (2009): 257-267.

\title{
Effects of perch on feed consumption and behaviour of caged laying hens
}

\author{
Eija Valkonen ${ }^{1}$, Reine Rinne ${ }^{2}$ and Jarmo Valaja ${ }^{1}$ \\ ${ }^{\prime}$ MTT Agrifood Research Finland, Animal Production Research, FI-31600 Jokioinen, Finland, \\ email:firstname.lastname@mtt.fi, \\ ${ }^{2}$ University of Helsinki, Department of Animal Science, PO Box 28, \\ FI-00014 University of Helsinki, Finland
}

\begin{abstract}
This experiment studied the effects of perches in furnished cages on behaviour and feed consumption of laying hens. The study used 352 Lohmann Selected Leghorn (LSL) hens. The hens were housed at 16 weeks of age in furnished cages in groups of 8 birds. The experiment lasted for 205 days. The treatments were: perches present from 16 weeks of age (P16), perches present from 19 weeks of age (P19), and no perches present (NP). Feed consumption and egg production were measured over the pre-laying period and six 4-week laying periods. The number of hens on perch, in nest and litter box was recorded at various ages. The behaviour of 3 hens per treatment was observed using instantaneous sampling at every 5 minutes, so that the observations of each hen covered one light period (14.5 hours). The treatments had no significant effects on feed consumption after the pre-laying period. Feed conversion ratio ( $\mathrm{kg}$ feed $\mathrm{kg}^{-1}$ eggs) was favourable in P16 in comparison to NP during the periods 2-4. During the observations after the lights-out NP birds tended to be more frequently in nests, than P16 birds. NP birds spent more time on the cage floor, were recumbent more often, and sitting more rarely in comparison to P16 birds.

Based on the results of this study, perches may have advantageous effect on feed conversion ratio in furnished cages.
\end{abstract}

Key-words: feed consumption, egg production, welfare 


\section{AGRICULTURAL AND FOOD SCIENCE}

Valkonen, E. et al. Effects of perch on laying hens

\section{Introduction}

Conflicting results have been published on the effects of furnishing cages on feed consumption. Lower feed intake has been reported in cages with perches (Tauson and Jansson 1988, Braastad 1990, Glatz and Barnett 1996). It has also been suggested, that housing in furnished cages could diminish energy requirements of laying hens (Valkonen et al. 2006). This suggestion was based on the observations that perches and dust bath (or litter) may diminish plumage deterioration, and that lower activities and resting cuddled up side by side have been observed in cages with perches (Tauson and Jansson 1988, Braastad 1990). However, e.g. Hetland et al. (2003 and 2004) reported higher feed consumption in furnished cages in comparison to conventional cages. The activity of birds tends to increase with increasing group size when associated with larger total area (Carey et al. 1995); this is true in furnished cages and may consequently increase feed consumption in those. Increased group size may also negatively affect plumage cover (Appleby et al. 2002, Hetland et al. 2003, Weitzenbürger et al. 2006).

The effects of perch on production and feed intake have been studied before mainly in conventional cages housing only up to 5 hens (e.g. Tauson 1984). In addition to this, literature holds comparisons between conventional and furnished cages (e.g. Abrahamsson et al. 1995, and Hetland et al. 2004). In these comparisons group size and space allowance typically differs between the cage types compared. The objective of this experiment was to study the effects of perches in furnished cages on performance, exterior appearance, and behaviour of laying hens without confounding effects of group size and total cage area.

\section{Materials and methods}

A total of 352 Lohmann Selcted Leghorn-Classic Layer (LSL) pullets were housed at 16 weeks of age in an environmentally controlled windowless room in 8-hen furnished cages (TAPE, Triotec Oy, Koski TL, Finland). These cages measured $120 \times$ $50 \times 48 \mathrm{~cm}$ (width $\times$ depth $\times$ height) and provided $600 \mathrm{~cm}^{2}$ of usable area and $750 \mathrm{~cm}^{2}$ of total cage area per hen. The length of feed trough per hen was about $12 \mathrm{~cm}$. Before housing, a commercial farm reared the birds in conventional cages. The experiment lasted for 205 days. The pre-laying period lasted for 36 days, and the laying period lasted for 169 days or 6 four-week periods. Prelaying period ended when all experimental units had reached $50 \%$ production (the number of eggs laid equals at least 0.5 times the number of birds on 3 consecutive days). We used 44 cages; 12 cages were fully furnished with perches, a nest, and a litter area above the nest in accordance with Council Directive 1999/74/EC (Commission of the European Communities 1999) (Control treatment or P16). From 32 cages, the perches had been removed, but all other features were equal to the control cages. In 12 of these cages, perches were installed when the hens were 19 weeks of age (P19), and 20 of these cages remained without perches through the experiment (NP). Two adjacent cages comprised an experimental unit ( $\mathrm{n}=6,6$ and 10 for P16, P19 and NP, respectively). In NP cages a sheet of metal, which was a part of the cage construction, and which was covered with a wooden perch in other 2 treatments, ran through the middle of the cage perpendicularly to the feed trough. In P16 and P19 cages, three wooden perches ran through the cages perpendicularly to the feed trough. These perches had angular cross-section (width $23 \mathrm{~mm}$, height $30 \mathrm{~mm}$ ) and rounded bevels. A plastic strip curtain separated the nest from the main cage. Litter area was daily available to hens for $5 \mathrm{~h}$, and it was closed with an automatic grid gate during the nights and the first $8.5 \mathrm{~h}$ of the light period, to prevent laying in the litter area.

From housing at 16 weeks of age until $50 \%$ production at about 21 weeks of age, the hens received pelleted pre-layer feed composed of barley, wheat, oats, and soybean meal together with rapeseed oil, limestone, and vitamin and mineral premixes. The pre-layer feed had 10.6 MJ metabolisable energy (ME) $\mathrm{kg}^{-1}$ feed, and $177.9 \mathrm{~g}$ crude 


\section{AGRICULTURAL AND FOOD SCIENCE}

Vol. 18 (2009): 257-267.

protein $\mathrm{kg}^{-1}$ feed. Calcium and available phosphorus content of the pre-layer diet was 37.1 and $4.6 \mathrm{~g}$ $\mathrm{kg}^{-1}$, respectively. The experimental units reached $50 \%$ production at 148 days of age at the latest. The feed was changed to a layer feed, and the second experimental period started at 149 days of age. The pelleted layer diet comprised of the same ingredients as the pre layer diet, and had 10.6 MJ $\mathrm{ME} \mathrm{kg}^{-1}$ feed, a crude protein content of $186.2 \mathrm{~g}$ $\mathrm{kg}^{-1}$, calcium content of $38.9 \mathrm{~g} \mathrm{~kg}^{-1}$, and available phosphorus content of $4.6 \mathrm{~g} \mathrm{~kg}^{-1}$. A chain feeder ran once a day to provide hens their feed. To ensure ad libitum access to feed, the hens received approximately twice the amount of feed they were expected to consume daily. Leftover feed was collected separately for each experimental unit ( 2 adjacent cages) and reused for the same unit. Leftover feed was weighed and feed consumption assessed at the end of each period. Feed conversion ratio (FCR, $\mathrm{kg}_{\text {feed }} \mathrm{kg}^{-1}$ eggs) was calculated over each period. Feed and water were available ad libitum during the experiment. During the first week following housing, the hens received $10 \mathrm{~h}$ of light per day. After that, at 17 weeks of age the photoperiod was increased to $14.5 \mathrm{~h}$. The lights went out in two steps to imitate dusk: the first 2 of the 4 light lines went out about 3 minutes before the rest of the lines.

Egg weight and number of eggs were recorded daily, and the mean production was calculated for each 4-week period. The exterior appearance of hens from every second cage was assessed at 27 and 43 weeks of age, using the method of Tauson et al. (1984). This method assesses feather condition, and lesions in feet and skin on a scale from 1 (poorest) to 4 (best). The traits assessed were: plumage condition in neck, breast, back, wings, tail, and around the cloaca, and condition of feet (pododermatitis and hyperkeratosis). Plumage scores of the six body parts sum up to total score for plumage condition ranging from 6 to 24 points. Mortality was recorded daily, and cumulative mortalities were calculated at the end of the pre-laying period and at the end of the experiment.

The location of each bird was recorded on 3 consecutive days at 17, 20, 23, 26, 34 and 42 weeks of age, and at 3 separate times each day: at 6 and $11.5 \mathrm{~h}$ after lights-on and at $1 \mathrm{~h}$ after lightsout using scan sampling. The observer counted the number of birds on each perch, and in the nest. Birds sitting or standing on the metal sheet in cages without perches were considered as perching. On the same days the number of hens in litter boxes was recorded at 3 separate times: at the time of opening of the litter boxes, and at $30 \mathrm{~min}$, and at $2 \mathrm{~h}$ after the opening of the litter boxes.

The behaviour of 3 randomly selected individual hens per each treatment was recorded. The observations took place during a 2-week period at the age of 35-36 weeks, so that the observations of each hen covered one light period (14.5 h). The behaviour, posture and location of each observed hen were recorded using direct observations and instantaneous sampling at every 5 minutes. The behaviours, postures and locations recorded are presented in Table 1.

Statistical analyses were performed using the GLM procedure of SAS (SAS Institute Inc., Cary, NC). Production variables were subjected to repeated measures analysis of variance using the following model: $\mathrm{Y}_{\mathrm{ij}}=\mu+\mathrm{t}_{\mathrm{i}}+\delta_{\mathrm{i}}+\mathrm{p}_{\mathrm{j}}+(\mathrm{pxt})_{\mathrm{ij}}+\varepsilon_{\mathrm{ij}}$, where $Y_{i j}=$ observation, $\mu=$ general mean, $t_{i}=$ effect of treatment $(i=1, \ldots, 3), \delta_{i}=$ error term for effect of treatment, $p_{j}=$ effect of period $(j=1, \ldots, 7)$, and $\varepsilon_{\mathrm{ij}}=$ the experimental error term. Results from behavioural observations and bird location were analyzed as frequencies. These frequencies, live weights and condition scorings were evaluated by analysis of variance using the following model: $\mathrm{Y}_{\mathrm{ij}}$ $=\mu+t_{i}+\varepsilon_{i}$, where $Y_{i}=$ observation, $\mu=$ general mean, $\mathrm{t}_{\mathrm{i}}=$ effect of treatment $(\mathrm{i}=1, \ldots, 3)$, and $\varepsilon_{\mathrm{i}}$ $=$ the experimental error term. Comparisons between the control treatment (P16) and NP or P19 were performed with Dunnett's t-test. The residuals were plotted against fitted values to ascertain the normality of the experimental data. Arcsine transformations were made when required (for frequency or percentage observations) to attain normality of the data. In the tables, the original least square means and standard errors (SE) are presented. 


\section{AGRICULTURAL AND FOOD SCIENCE}

Valkonen, E. et al. Effects of perch on laying hens

Table 1. Activity, posture, and location options recorded during the behavioural observations of individual hens.

\begin{tabular}{lll}
\hline Activity & Posture & Location \\
\hline Body shaking & Recumbent & Floor \\
Chasing other hen & Sitting & Litter box \\
Drinking & Standing & Nest \\
Dust bathing & & Nest door \\
Eating & & Perch (1, 2, or 3) \\
Pecking & \\
Preening & \\
Scratching & \\
Sleeping (Eyes closed or head under wing) & \\
Stretching & \\
Walking & \\
Wing flapping & \\
\hline
\end{tabular}

\section{Results}

The treatments had no significant effects on live weight, laying rate, egg weight, or egg mass produced per hen day ${ }^{-1}$ (Table 2). However, birds initially housed without perches (NP and P19) consumed more feed during the pre-laying period, than those housed with perches (P16) $(p<0.05)$. Later during the laying period, this difference diminished, and it was not statistically significant. However, FCR was favourable in groups having early access to perches (P16) in comparison to no perches (NP) during the periods $2-4(p<0.05)$. There were no significant differences in mortality between the treatments.

Birds with early access to perches (P16) had more pododermatitis (or bumble foot) than birds without perches (NP) $(p<0.05)$ (Table 3). On the other hand, NP birds had more hyperkeratosis than P16 birds at 43 weeks of age $(p<0.05)$. At 27 weeks of age keel bone deformities were more common in P16 in comparison to NP birds $(p<0.05)$. Plumage condition did not differ significantly between the treatments.
Some of the birds in cages without perches used the metal sheet running through the cage as a perch (Table 4). There were no differences in perching frequencies during the day-time observations between P16 and P19 after the installing of the perches in P19. However, at 20 weeks of age fewer birds in P19 were perching during the observations after the lights-out, but later this difference vanished. During the observations $1 \mathrm{~h}$ after the lights-out, birds housed without perches (NP) tended to be more frequently in nests, than the P16 birds (Table 5). This difference was statistically significant at 20 and 23 weeks of age. There were no significant differences between the treatments in the litter box use (results not shown). The variation in litter box use within the treatments was considerably high. High proportion of eggs (95-98\%) was laid in the nest in all treatments, and no effects of presence or absence of perch was detected (results not shown).

In behavioural observations of individual hens, birds in cages without perches (NP) spent more time on the cage floor $(94.3 \%$ of observations, $\mathrm{SE}=5.059)$ than $\mathrm{P} 16$ birds (56.2\% of observations, $\mathrm{SE}=5.059)(p=0.001)$. Overall, hens in cages with perches spent $28.2 \%$ of the daytime on perches. 
Vol. 18 (2009): 257-267.

Table 2. Production performance and mortality (Least square means) as influenced by presence or absence of perches in furnished cage.

\begin{tabular}{|c|c|c|c|c|c|c|c|}
\hline \multirow[b]{3}{*}{$\mathrm{n}$} & \multicolumn{3}{|c|}{ Treatment ${ }^{1)}$} & \multirow{3}{*}{$\mathrm{SE}^{2)}$} & \multirow{3}{*}{ F-test ${ }^{3)}$} & \multicolumn{2}{|c|}{ Dunnett's t-test ${ }^{4)}$} \\
\hline & P16 & P19 & NP & & & P16 vs. P19 & P16 vs. NP \\
\hline & 6 & 6 & 10 & & & & \\
\hline \multicolumn{8}{|l|}{ Laying rate, $\%$} \\
\hline Pre-laying period & 23.8 & 22.6 & 23.3 & 1.686 & 0.881 & 0.829 & 0.956 \\
\hline Periods $2-7$ & 95.5 & 95.5 & 95.1 & 2.076 & 0.895 & 1.000 & 0.889 \\
\hline \multicolumn{8}{|l|}{ Egg weight, $g$} \\
\hline Pre-laying period & 47.7 & 48.4 & 47.8 & 0.572 & 0.660 & 0.641 & 0.998 \\
\hline Periods $2-7$ & 60.9 & 60.7 & 60.9 & 1.112 & 0.948 & 0.743 & 0.993 \\
\hline \multicolumn{8}{|c|}{ Egg mass, g per hen day ${ }^{-1}$} \\
\hline Pre-laying period & 11.3 & 10.9 & 11.1 & 0.792 & 0.918 & 0.881 & 0.950 \\
\hline Periods $2-7$ & 58.2 & 58.0 & 58.0 & 1.671 & 0.976 & 0.940 & 0.842 \\
\hline \multicolumn{8}{|c|}{ Feed consumption, g per hen day ${ }^{-1}$} \\
\hline Pre-laying period & 80 & 85 & 84 & 1.230 & 0.021 & 0.021 & 0.029 \\
\hline Period 2 & 104 & 106 & 106 & 1.298 & 0.472 & 0.444 & 0.443 \\
\hline Period 3 & 109 & 111 & 110 & 1.347 & 0.455 & 0.347 & 0.656 \\
\hline Period 4 & 109 & 112 & 110 & 1.393 & 0.486 & 0.382 & 0.806 \\
\hline Period 5 & 110 & 113 & 113 & 1.490 & 0.218 & 0.375 & 0.151 \\
\hline Period 6 & 112 & 113 & 114 & 1.222 & 0.262 & 0.509 & 0.180 \\
\hline Period 7 & 117 & 119 & 119 & 1.446 & 0.367 & 0.375 & 0.375 \\
\hline \multicolumn{8}{|c|}{ Feed conversion ratio, $\mathrm{kg}$ feed $\mathrm{kg}^{-1}$ eggs } \\
\hline Pre-laying period & 7.27 & 7.92 & 7.81 & 0.527 & 0.645 & 0.398 & 0.430 \\
\hline Period 2 & 2.01 & 2.06 & 2.07 & 0.016 & 0.041 & 0.105 & 0.026 \\
\hline Period 3 & 1.88 & 1.94 & 1.95 & 0.022 & 0.071 & 0.163 & 0.046 \\
\hline Period 4 & 1.82 & 1.90 & 1.89 & 0.015 & 0.004 & 0.004 & 0.006 \\
\hline Period 5 & 1.85 & 1.89 & 1.90 & 0.019 & 0.239 & 0.408 & 0.165 \\
\hline Period 6 & 1.89 & 1.90 & 1.90 & 0.021 & 0.986 & 0.981 & 0.986 \\
\hline Period 7 & 1.92 & 1.96 & 1.94 & 0.021 & 0.287 & 0.200 & 0.526 \\
\hline \multicolumn{8}{|l|}{ Live weight, $\mathrm{g}$} \\
\hline at 16 weeks of age & 1150 & 1159 & 1162 & 5.8052 & 0.915 & 0.986 & 0.952 \\
\hline at 21 weeks of age & 1528 & 1552 & 1544 & 10.797 & 0.301 & 0.231 & 0.386 \\
\hline at 45 weeks of age & 1806 & 1844 & 1816 & 18.367 & 0.330 & 0.265 & 0.876 \\
\hline \multicolumn{8}{|l|}{ Mortality, \% } \\
\hline Pre-laying period & 0.00 & 1.04 & 0.00 & 0.534 & 0.275 & 0.300 & 1.000 \\
\hline Periods $2-7$ & 3.13 & 1.04 & 1.25 & 1.161 & 0.373 & 0.353 & 0.349 \\
\hline
\end{tabular}

1) $\mathrm{P} 16=$ perches available from the housing at 16 weeks of age, $\mathrm{P} 19=$ perches installed at 19 weeks of age, $\mathrm{NP}=$ no perches available

2) Standard error for groups P16 and P19. SE $=\left(\right.$ variance $\left.^{-2}\right)\left(\mathrm{n}^{-2}\right)^{-1}$, thus the standard error for group NP is $0.7746 \times \mathrm{SE}$ presented in the table.

3) $p$-values for F-test

4) $p$-values for comparisons of experimental treatments (NP and P19) with control (P16). 


\section{AGRICULTURAL AND FOOD SCIENCE}

Valkonen, E. et al. Effects of perch on laying hens

Table 3. Exterior appearance (Least square means) of hens at different ages as influenced by presence or absence of perches in furnished cage. Range of scores were from 6 to 26 (plumage) and from 1 to 4, where higher scores indicate better condition.

\begin{tabular}{|c|c|c|c|c|c|c|c|}
\hline \multirow[b]{3}{*}{$\underline{\mathrm{n}}$} & \multicolumn{3}{|c|}{ Treatment $^{1)}$} & \multirow{3}{*}{$\mathrm{SE}^{2)}$} & \multirow{3}{*}{ F-test ${ }^{3)}$} & \multicolumn{2}{|c|}{ Dunnett's t-test ${ }^{4)}$} \\
\hline & $\mathrm{P} 16$ & P19 & NP & & & P16 vs. P19 & P16 vs. NP \\
\hline & 6 & 6 & 10 & & & & \\
\hline \multicolumn{8}{|c|}{ Plumage condition score } \\
\hline at $27 \mathrm{wk}$ & 23.7 & 23.6 & 23.3 & 0.2777 & 0.487 & 0.861 & 0.393 \\
\hline at $43 \mathrm{wk}$ & 20.6 & 20.0 & 19.3 & 0.6183 & 0.291 & 0.698 & 0.209 \\
\hline \multicolumn{8}{|c|}{ Keel bone score } \\
\hline at $27 \mathrm{wk}$ & 3.6 & 3.7 & 3.8 & 0.076 & 0.054 & 0.579 & 0.037 \\
\hline at $43 \mathrm{wk}$ & 2.6 & 2.3 & 2.9 & 0.117 & 0.008 & 0.112 & 0.309 \\
\hline \multicolumn{8}{|c|}{ Pododermatitis score } \\
\hline at $27 \mathrm{wk}$ & 3.7 & 3.7 & 3.9 & 0.052 & 0.002 & 0.995 & 0.005 \\
\hline at $43 \mathrm{wk}$ & 3.7 & 3.7 & 4.0 & 0.067 & 0.001 & 0.849 & 0.006 \\
\hline \multicolumn{8}{|c|}{ Hyperkeratosis score } \\
\hline at $27 \mathrm{wk}$ & 3.8 & 3.9 & 3.7 & 0.061 & 0.095 & 0.735 & 0.259 \\
\hline at $43 \mathrm{wk}$ & 3.6 & 3.8 & 3.4 & 0.087 & 0.005 & 0.473 & 0.043 \\
\hline
\end{tabular}

P16 birds tended to sit more often in comparison to NP birds (34.4 and $13.5 \%$ of observations, respectively; $\mathrm{SE}=6.103 ; p=0,072)$. However, NP birds were recumbent more often in comparison to P16 birds ( 8.0 and $1.5 \%$ of observations, respectively; $\mathrm{SE}=1.44 ; p=0.026$ ). There were no other statistically significant differences between the treatments in behaviour (results not shown).

In the behavioural observations of individual hens during the day time, we found that birds without perches tended to sleep on the cage floor (100\% of observations) where as birds with access to perches slept mainly on a perch (79\%). During the observations of individual hens, dustbathing, or sham dustbathing, occurred solely on the cage floor in cages without perches, and mostly (83\%) on the cage floor in cages with perches. Of all dustbathing and sham dustbathing observations, 54\% occurred while the litter area was closed (results not shown).

\section{Discussion}

The aim of this experiment was to study the effects of perches in furnished cages on production, feed intake, exterior appearance, and behaviour of laying hens, without the confounding effects of group size and available cage area, both of which may affect on bird behaviour and feed consumption.

We found no significant differences in feed consumption between the perch treatments after the pre-laying period. This is in contrast to the findings of Braastad (1990), and Glatz and Barnett 
Vol. 18 (2009): 257-267.

Table 4. Proportion of hens perching (Least square means) during scan observations at different ages as influenced by presence or absence of perches in furnished cage. Birds sitting or standing on the metal sheet in cages without perches (NP) were considered as perching.

\begin{tabular}{|c|c|c|c|c|c|c|c|}
\hline \multirow[b]{3}{*}{$\mathrm{n}$} & \multicolumn{3}{|c|}{ Treatment $^{1)}$} & \multirow{3}{*}{$\mathrm{SE}^{2)}$} & \multirow{3}{*}{ F-test ${ }^{3)}$} & \multicolumn{2}{|c|}{ Dunnett's t-test ${ }^{4)}$} \\
\hline & P16 & P19 & NP & & & P16 vs. P19 & P16 vs. NP \\
\hline & 6 & 6 & 10 & & & & \\
\hline \multicolumn{8}{|c|}{$\begin{array}{l}\text { Proportion of hens, } \% \text { perching at } 6 \mathrm{~h} \text { after } \\
\text { lights-on }\end{array}$} \\
\hline at $17 \mathrm{wk}$ & 72.6 & 14.9 & 13.5 & 2.121 & $<0.001$ & $<0.001$ & $<0.001$ \\
\hline at $20 \mathrm{wk}$ & 47.6 & 44.4 & 4.8 & 2.645 & $<0.001$ & 0.751 & $<0.001$ \\
\hline at $23 \mathrm{wk}$ & 42.4 & 40.2 & 5.8 & 2.208 & $<0.001$ & 0.781 & $<0.001$ \\
\hline at $26 \mathrm{wk}$ & 41.4 & 34.5 & 6.7 & 2.571 & $<0.001$ & 0.301 & $<0.001$ \\
\hline at $34 \mathrm{wk}$ & 42.3 & 31.5 & 4.0 & 3.247 & $<0.001$ & 0.123 & $<0.001$ \\
\hline at $42 \mathrm{wk}$ & 36.8 & 34.9 & 6.5 & 3.061 & $<0.001$ & 0.910 & $<0.001$ \\
\hline \multicolumn{8}{|c|}{ perching at $11.5 \mathrm{~h}$ after lights-on } \\
\hline at $17 \mathrm{wk}$ & 49.3 & 8.3 & 7.3 & 2.356 & $<0.001$ & $<0.001$ & $<0.001$ \\
\hline at $20 \mathrm{wk}$ & 32.3 & 23.8 & 5.0 & 2.360 & $<0.001$ & 0.307 & $<0.001$ \\
\hline at $23 \mathrm{wk}$ & 26.0 & 21.0 & 1.3 & 1.158 & $<0.001$ & 0.221 & $<0.001$ \\
\hline at $26 \mathrm{wk}$ & 20.7 & 16.2 & 0.6 & 1.945 & $<0.001$ & 0.285 & $<0.001$ \\
\hline at $34 \mathrm{wk}$ & 19.5 & 19.0 & 0.6 & 1.895 & $<0.001$ & 0.993 & $<0.001$ \\
\hline at $42 \mathrm{wk}$ & 28.0 & 25.5 & 1.9 & 1.615 & $<0.001$ & 0.714 & $<0.001$ \\
\hline \multicolumn{8}{|c|}{ perching at $1 \mathrm{~h}$ after lights-out } \\
\hline at $17 \mathrm{wk}$ & 64.9 & 19.4 & 20.2 & 3.815 & $<0.001$ & $<0.001$ & $<0.001$ \\
\hline at $20 \mathrm{wk}$ & 81.9 & 68.3 & 14.0 & 2.343 & $<0.001$ & 0.003 & $<0.001$ \\
\hline at $23 \mathrm{wk}$ & 75.7 & 73.3 & 13.1 & 2.327 & $<0.001$ & 0.741 & $<0.001$ \\
\hline at $26 \mathrm{wk}$ & 53.3 & 47.6 & 5.4 & 1.496 & $<0.001$ & 0.425 & $<0.001$ \\
\hline at $34 \mathrm{wk}$ & 68.3 & 62.7 & 7.6 & 2.434 & $<0.001$ & 0.336 & $<0.001$ \\
\hline at $42 \mathrm{wk}$ & 74.9 & 75.9 & 10.6 & 2.762 & $<0.001$ & 0.976 & $<0.001$ \\
\hline
\end{tabular}

(1996) in conventional 3-hen cages. Our results on feed consumption agree with the findings of Abrahamsson and Tauson (1993), who reported no significant differences between cages with or without perches. However, we found a significant difference between the effects of P16 and NP in FCR during the periods 2-4, which is in agreement with the findings of Glatz and Barnett (1996), who also reported favourable FRC in cages equipped with perches. One explanation for the lack of the effect of perches on FCR later in the laying period may be red mite infestation, which was detected during the $4^{\text {th }}$ period. Red mites may make hens restless, and affect their activity, production, and feed intake. However, in comparison to earlier experiments in our institute with mite free flocks, 
Valkonen, E. et al. Effects of perch on laying hens

Table 5. Proportion of hens in the nest during scan observations 1 hour after lights-out at different ages as influenced by presence or absence of perches in furnished cage.

\begin{tabular}{|c|c|c|c|c|c|c|c|}
\hline \multirow[b]{3}{*}{$\mathrm{n}$} & \multicolumn{3}{|c|}{ Treatment $^{1)}$} & \multirow{3}{*}{$\mathrm{SE}^{2)}$} & \multirow{3}{*}{ F-test ${ }^{3)}$} & \multicolumn{2}{|c|}{ Dunnett's t-test $\left.{ }^{4}\right)$} \\
\hline & P16 & P19 & NP & & & P16 vs. P19 & P16 vs. NP \\
\hline & 6 & 6 & 10 & & & & \\
\hline \multicolumn{8}{|c|}{$\begin{array}{l}\text { Proportion of hens, } \% \text { in the nest at } \\
1 \mathrm{~h} \text { after lights-out }\end{array}$} \\
\hline at $17 \mathrm{wk}$ & 20.1 & 29.5 & 26.3 & 4.215 & 0.2401 & 0.173 & 0.360 \\
\hline at $20 \mathrm{wk}$ & 10.1 & 21.5 & 25.4 & 1.869 & $<0.001$ & 0.003 & $<0.001$ \\
\hline at $23 \mathrm{wk}$ & 9.0 & 9.9 & 16.7 & 1.970 & 0.009 & 0.758 & 0.009 \\
\hline at $26 \mathrm{wk}$ & 9.4 & 8.5 & 12.5 & 1.667 & 0.158 & 0.886 & 0.284 \\
\hline at $34 \mathrm{wk}$ & 10.2 & 10.7 & 16.9 & 2.262 & 0.045 & 0.999 & 0.067 \\
\hline at $42 \mathrm{wk}$ & 10.5 & 8.2 & 15.7 & 2.348 & 0.055 & 0.697 & 0.184 \\
\hline
\end{tabular}

the laying rate and FCR in the present experiment were good and thus not compromised by the red mite infestation.

In the present experiment, there were no significant differences between the treatments in laying rate, egg weight, egg mass produced, or body weight of the birds. This agrees with the results of Braastad (1990), Appleby et al. (1992), and Abrahamsson and Tauson (1993). However, this is in contrast to the findings of Tauson (1984), who reported lower egg weight and body weight in birds with perches, and Glatz and Barnett (1996), who in addition to the lighter egg and body weight reported lower laying rate in cages with perches.

Our results on plumage condition agree with Abrahamsson and Tauson (1993), and Appleby et al. (1992), who found no significant effects of perches on feather cover. There are, however, also conflicting results reported in the literature e.g. Tauson (1984), who reported inferior plumage cover in cages with perches, and Braastad (1990), who reported better plumage in perch cages than in cages without perches. Keel bone deformations are often associated with presence of perches (e.g.
Abrahamsson et al. 1996), and our results agree with this, although, at the age of 43 weeks, the difference between keel bone scores of the groups P16 and NP was not statistically significant. In agreement with the results of the present study, Tauson and Abrahamsson (1994) and Glatz and Barnett (1996) reported feet pad lesions (pododermatitis) to be more common in cages with perches, but in contrast, Appleby et al. (1992) reported improved foot condition in cages with perches. These differences may stem from different perch designs and configuration, and different hybrids used in the experiments. Our results on the prevalence of hyperkeratosis agree with those of Tauson and Abrahamsson (1994), who reported less hyperkeratosis in hens housed in cages with perches.

It is well established, that hens are motivated to rest on perches at night (e.g. Olsson and Keeling 2000). This motivation expresses itself amid present study in the observation that the hens in cages without perches were roosting on the thin metal sheet running through the cage. The average proportion of birds perching during the night-time inspections in P16 and P19 groups after installation 


\section{AGRICULTURAL AND FOOD SCIENCE}

Vol. 18 (2009): 257-267.

of perches was low (69.8 and $65.6 \%$ respectively), when compared with previous studies in furnished cages e.g. 91\% according to Abrahamsson and Tauson (1997) and $85.9 \%$ reported by Wall and Tauson (2007). In the present experiment, there were about $17 \mathrm{~cm}$ perch per hen, which should allow all of the hens roost simultaneously (Appleby 1995). Had the perch space been restrictive, roosting would probably have diminished during the experiment, as hens gain more weight. One reason for the low proportion of hens perching may be red mite infestation. Red mites may disturb hens particularly in the night. Earlier results in our henhouse, with a flock without red mite infestation, showed a proportion of $79 \%$ of birds on perches during the night-time inspections. Moreover, quite a few hens spent their nights in the nest. Nest may simply be a preferred place to some of the hens, or there may have been social factors affecting the choice of roosting place. Wall and Tauson (2007) reported that white hybrids are more prone to spend the night in nest in comparison to brown hybrids. In contrast to our results, Barnett et al. (2005) reported that in the presence of perches eggs were more likely to be laid in the nest than in the absence of perches.

Time spent on perches during daytime observations of individual hens was similar to what has been reported earlier (Appleby et al. 1992, Appleby et al. 1993).

Sham dustbathing behaviour on the cage floor is often seen in furnished cages despite the presence of a dustbath and litter material (e.g. Olsson and Keeling 2002). Olsson and Keeling (2002) suggest that this may depend on the rearing conditions of the birds. Wall (2003) also suggests that absence of litter in the early life of birds may affect litter use. However, Wichman and Keeling (2007) present results which suggest that also birds without early experience of litter are motivated to dustbathe in a functional substrate. Birds in the present experiment were reared in conventional cages without litter. In addition, access to litter area was restricted, and about half of the dustbathing observations made occurred before the litter area was opened. Initiation of dustbathing peaks 6-7 h after lights-on (Vestergaard 1982) and in the present experiment litter area was opened $8.5 \mathrm{~h}$ after lights-on. Another factor restricting the use of the litter area may have been the location of the litter area on the top of the nest box, as the ease of access may affect the use of the litter area (Olsson and Keeling 2002, Wall 2003).

According to the results of the present experiment, perches in furnished cages do not significantly affect the feed consumption of laying hens. However, perches may have advantageous effect on feed conversion ratio. This may be accounted for less active behaviour in cages with perches which Braastad (1990) and Matsui et al. (2004) have reported.

Acknowledgements. The Raisio plc Research Foundation supported this experiment. The authors would like to thank Kaarina Karppinen, and Tapani Ratilainen for their skilful technical assistance.

\section{References}

Abrahamsson, P. \& Tauson, R. 1993. Effect of perches at different positions in conventional cages for laying hens of two different strains. Acta Agriculturæ Scandinavica, Section A, Animal Science 43: 228-235.

Abrahamsson, P. \& Tauson, R. 1997. Effects of group size on performance, health and birds' use of facilities in furnished cages for laying hens. Acta Agriculturæ Scandinavica, Section A, Animal Science 47: 254-260.

Abrahamsson, P., Tauson, R. \& Appleby, M. C. 1995. Performance of four hybrids of laying hens in modified and conventional cages. Acta Agriculturæ Scandinavica, Section A, Animal Science 45: 286-296.

Abrahamsson, P., Tauson, R. \& Appleby, M. C. 1996. Behaviour, health and integument of four hybrids of laying hens in modified and conventional cages. British Poultry Science 37: 521-540.

Appleby, M. C. 1995. Perch length in cages for medium hybrid laying hens. British Poultry Science 36: 23-31.

Appleby, M. C., Smith, S. F. \& Hughes, B. O. 1992. Individual perching behaviour of laying hens and its effects in cages. British Poultry Science 33: 227-238.

Appleby, M. C., Smith, S. F. \& Hughes, B. O. 1993. Nesting, dust bathing and perching by laying hens in cages: Effects of design on behaviour and welfare. British Poultry Science 34: 835-847.

Appleby, M. C., Walker, A. W., Nicol, C. J., Lindberg, A. C., Freire, R., Hughes, B. O. \& Elson, H. A. 2002. Development of furnished cages for laying hens. British Poultry Science 43: 489-500.

Barnett, J. L., Cronin, G. M., Tauson, R., Downing, J. A., Janardhana, V., Lowenthal, J. W. \& Butler, K. L. 2005. The effects of a perch, dust bath and nest box in fur- 


\section{AGRICULTURAL AND FOOD SCIENCE}

Valkonen, E. et al. Effects of perch on laying hens

nished cages on the welfare of laying hens. Animal Science Papers and Reports 23 (Supplement 1): 111-119.

Braastad, B. O. 1990. Effects on behaviour and plumage of a key-stimuli floor and perch in triple cages for laying hens. Applied Animal Behaviour Science 27: 127-139.

Carey, J. B., Kuo, F. L. \& Anderson, K. E. 1995. Effects of cage population on the productive performance of layers. Poultry Science 74: 633-637.

CEC. 1999. Commission of the European Communities. Council Directive 1999/74/EC of 19 July: Laying down minimum standards for the protection of laying hens. The Official Journal of the European Community. L 203: 53-57.

Glatz, P. C. \& Barnett, J. L. 1996. Effect of perches and solid sides on production, plumage and foot condition of laying hens housed in conventional cages in naturally ventilated shed. Australian Journal of Experimental Agriculture 36: 269-275.

Hetland, H., Svihus, B., Lervik, S., \& Moe, R. 2003. Effect of feed structure on performance and welfare in laying hens housed in conventional and furnished cages. Acta Agriculturæ Scandinavica, Section A, Animal Science 53: 92-100.

Hetland, H., Moe, R. O., Tauson, R., Lervik, S. \& Svihus, B. 2004. Effect of including whole oats into pellets on performance and plumage condition in laying hens housed in conventional and furnished cages. Acta Agriculturæ Scandinavica, Section A, Animal Science 54: 206-212.

Matsui, K., Khalil, A. M. and Takeda, K.-I. 2004. Effects of perches on behavior, heart rate, body temperature and locomotor activity of caged hens. Journal of Poultry Science 41:120-130.

Olsson, I. A. S. \& Keeling, L. J. 2000. Night-time roosting in laying hens and the effect of thwarting access to perches. Applied Animal Behaviour Science 68: 243-256

Olsson, I. A. S. \& Keeling, L. J. 2002. No effect of social competition on sham dustbathing in furnished cages for laying hens. Acta Agriculturæ Scandinavica, Section A, Animal Science 52: 253-256.

Tauson, R. 1984. Effects of a perch in conventional cages for laying hens. Acta Agriculturæ Scandinavica, Section A, Animal Science 34: 193-209.

Tauson, R. \& Abrahamsson, P. 1994. Foot and skeletal disorders in laying hens. Effects of perch design, hybrid, housing system and stocking density. Acta Agriculturæ Scandinavica, Section A, Animal Science 44: 110-119.

Tauson, R., Ambrosen, T. \& Elvinger, K. 1984. Evaluation of procedures for scoring the integument of laying hens - independent scoring of plumage condition. Acta Agriculturæ Scandinavica, Section A, Animal Science 34: 400-408.

Tauson, R. \& Jansson, L. 1988. Effects on laying hens of additional features in cage design. Proceedings XVIII World's Poultry Congress, Nagoya, Japan. p. 11141115.

Valkonen, E., Venäläinen, E., Rossow, L., \& Valaja, J. 2006. Effects of dietary protein on egg production of laying hens housed in furnished or conventional cages. Acta Agriculturæ Scandinavica, Section A, Animal Science 56: 33-41.

Vestergaard, K. 1982. Dust-bathing in the domestic fowl - diurnal rhythm and dust deprivation. Applied Animal Ethology 8: 487-495.

Wall, H. 2003. Laying hens in furnished cages - Use of facilities, exterior egg quality and bird health. Acta Universitatis Agriculturae Sueciae - Agraria 406, Uppsala, Swedish University of Agricultural Sciences. $36 \mathrm{p}$.

Wall, H. \& Tauson, R. 2007. Perch arrangements in smallgroup furnished cages for laying hens. Journal of Applied Poultry Research 81: 333-339.

Weitzenbürger, D., Vits, A., Hamann, H. \& Distl, O. 2006. Evaluerung von Kleingruppenhaltungssystemen und ausgestalteten Käfigen hinsichtlich Brustbeindeformationen, Gefiederstatus, Krallenlänge und Körpermasse bei den Legelinien Lohmann Selected Leghorn und Lohmann Brown. (in German) Archiv für Tierzucht 49: 89-102.

Wichman, A. \& Keeling, L. J. 2007. Hens are motivated to dustbathe in peat irrespective of being reared with or without a suitable dustbathing substrate. Animal Behaviour 75: 1525-1533. 
Vol. 18 (2009): 257-267.

\title{
SELOSTUS
}

\section{Orsien vaikutus munivien kanojen käyttäytymiseen ja rehun kulutukseen}

\author{
Eija Valkonen, Reine Rinne ja Jarmo Valaja
}

MTT ja Helsingin yliopisto

Tutkimuksen tavoitteena oli selvittää orsien vaikutuksia munivien kanojen käyttäytymiseen, tuotantoon, rehunkulutukseen ja kuntoon. Kokeessa oli kolme käsittelyä: 1) Kanojen käytössä oli orret koko kokeen ajan 16 viikon iästä alkaen (P16, kontrolli), 2) kanojen käytössä oli orret 19 viikon iästä alkaen (P19) ja 3) kanoilla ei ollut orsia käytössään (NP). Kokeessa käytettiin 352 LSL-kanaa, jotka sijoitettiin kokeen alkaessa 16 viikon ikäisinä 44 häkkiin, kahdeksan kanan ryhmiin. Häkit olivat orsikäsittelyjä lukuun ottamatta Euroopan Unionin Neuvoston direktiivin 1999/74/EY mukaisia varusteltuja häkkejä. Kanojen rehunkulutus- ja munantuotantotiedot kerättiin kahden vierekkäisen häkin muodostamaa koeyksikköä kohden. Varusteiden käyttöä tarkkailtiin 17, 20, 23, 26, 34 ja 42 viikon iässä. Yhteensä yhdeksän yksittäisen kanan käyttäytymistä havainnoitiin noin kahden viikon aikana siten, että havaintoja saatiin kullekin kanalle koko vuorokauden valoisalta ajalta (14,5 h). Kanojen ulkoinen kunto arvioitiin 27 ja 43 viikon iässä.

Orret eivät vaikuttaneet kanojen munantuotantoon. Orret vähensivät kanojen rehunkulutusta munintaa edeltävän jakson aikana (16-21 viikon iässä), mutta myöhemmin erot eivät olleet tilastollisesti merkitseviä. Alkumuninnan aikana (21-33 viikon iässä) orret kuiten- kin paransivat kanojen rehunmuuntosuhdetta.

Tämän kokeen tulosten perusteella orret eivät vaikuttaneet kanojen höyhenpeitteen kuntoon. Sen sijaan orrellisissa häkeissä esiintyi enemmän anturapahkaa ja rintalastan vaurioita. Jalkojen ihon hyperkeratoosi puolestaan oli yleisempää orrettomissa häkeissä.

Orsien asennusajankohta ei merkittävästi vaikuttanut virikevarusteiden käyttöön. Häkeissä, joihin orret asennettiin vasta 19 viikon iässä, kanat käyttivät orsia 4 viikon kuluttua orsien asennuksesta yhtä paljon kuin 16 viikon iässä orret saaneet kanat. Orrettomissa häkeissä pidetyt kanat yöpyivät yleisemmin munintapesässä, kuin orrellisissa häkeissä pidetyt kanat, jotka yöpyivät enimmäkseen orsilla. Munintapesään munittujen munien määrään orret eivät vaikuttaneet. Orret saattavat edistää rauhallista yöpymistä ja vähentää pimeässä tapahtuvaa liikkumista ja syömistä. Tässä tutkimuksessa kanojen käyttäytymistä ei seurattu öisin, lukuun ottamatta pimeän aikaan tehtyjä orren ja pesän käyttöhavaintoja.

Tutkimuksen perusteella häkkien varustaminen orsin saattaa parantaa kanojen rehunhyötysuhdetta. Orret myös vähentävät pesässä yöpymistä, mikä puolestaan voi vaikuttaa edullisesti munien puhtauteen. 